\title{
The Earliest Stone Age Occupation of Eastern Middle Sweden
}

\author{
Per Gustafsson
}

\begin{abstract}
This paper presents a research project on the earliest Mesolithic settlement in eastern middle Sweden. Preliminary results from the excavations of four sites are discussed within the framework of the concepts "paleoenvironment", "natural landscape" and "cultural landscape". The benefit from considering the natural landscape as a result of cultural classification within unique cultural contexts is discussed, and some strategies for future research are introduced.
\end{abstract}

Per Gustafsson, Central Board of National Antiquities, UV Mälardalen, Box 17193, SE-104 62 Stockholm, Sweden.

\section{INTRODUCTION}

The purpose of this paper is to give an introduction to current research on early Mesolithic sites in eastern middle Sweden (fig. 1). My intention is to present some aspects of the present research on a paleoenvironment that was transformed into a cultural landscape of Mesolithic hunter-gatherers.

The so-called Gladö research project is carried out within the Central Board of National Antiquities, Department of Archaeological Investigations, UV Mälardalen. Four Mesolithic sites have been excavated - three of them preliminary and one more intensively - prior to planned mining activities and the building of a refuse recycling plant. The investigated area is situated on the Södertörn peninsula, c. $20 \mathrm{~km}$ south of Stockholm. Within the project a stratigraphical survey of wetlands in the area was carried out by the Department of Quaternary Research, Stockholm University (Risberg 1996). So far fieldwork has been carried out in 1995 and 1996.

\section{PALEOENVIRONMENTS AND CULTURAL LANDSCAPES}

Studies of prehistoric cultural landscapes have been carried out throughout the last two decades of archaeological research. In this paper the reader will come across some concepts used earlier in archacological literature but with different meanings. These concepts are environment, natural landscape and cultural landscape. The meaning of the concept "cultural landscape" and the way it has been studied have changed with the theoretical perspectives in use. During the last ten years or so cultural, ritual and individual aspects of landscape have been in focus. Earlier the cultural landscape was analysed in terms of natural resources, adaptation, human impact and economy (Welinder 1992). I prefer to use the term "paleoenvironment" in contrast to "landscape", with paleoenvironment referring to a reconstruction of the actual natural environment. Human beings may be present, but are not seen as culturally interacting. An environment is shaped by natural processes and may be transformed into a landscape (Tilley 1994). A landscape is a meaningful creation of human beings. The term "landscape" has been said to imply a culturally experienced environment. Tilley states that landscape is not a fixed environment but a structure in constant change in relation to humans, the relationship being in a constant dialectic. Landscapes are 

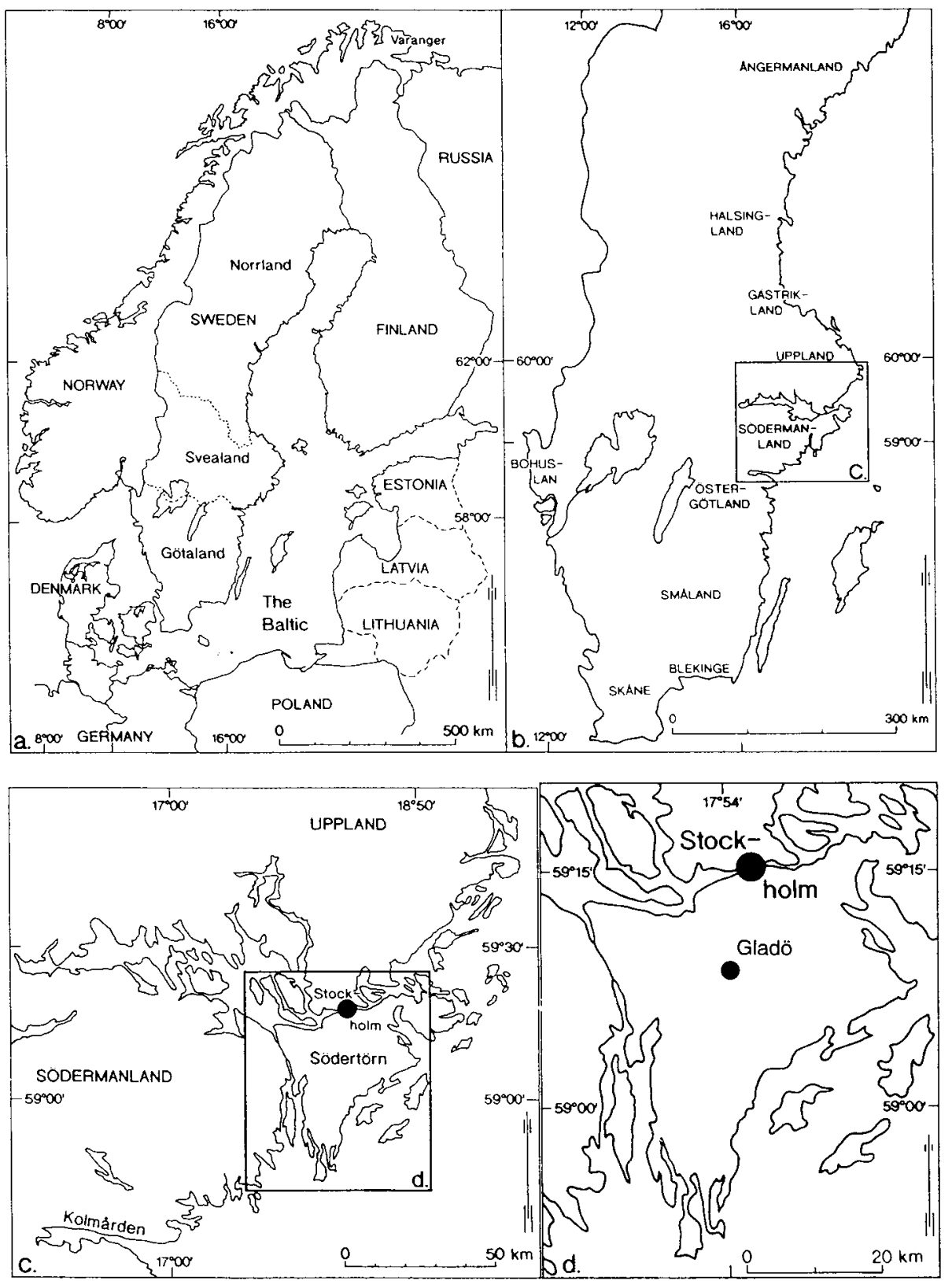

Fig. I. Location maps: a) northern Europe and the Baltic; b) southern and central Sweden; c) central part of eastern middle Sweden; d) Södertörn with Gladö marked. (Modified from Åkerlund et. al. 1995, fig. 1). 
believed to be experienced in practice and in life activities (Tilley 1994). Agneta Åkerlund (1996) discusses the importance of the physical setting for the formation of human attitudes and values. She discusses whether continuous changes in the physical environment can lead to the development of a mental capacity adjusted to complexity.

Stig Welinder (1993) discusses the concept of cultural landscape and presents six definitions of it, two of which are said to be relevant to archaeologists. One concerns the space in which people live, work and travel, and one concerns the fossil cultural landscape. Both aspects are interesting to consider when studying the Mesolithic of eastern middle Sweden. In my presentation this first definition of cultural landscape will correspond to my use of the term landscape, without for that matter trying to present an exact definition of the term "landscape". In the present paper the term "landscape" also corresponds to Orvar Löfgren's "landscape" and to Ulf Sporrong's term "historical landscape". Sporrong suggests the use of the term "historical landscape" instead of "cultural landscape", which according to him widens the perspective and permits the incorporation of topographical or geographical aspects of the landscape (Löfgren 1989; Sporrong 1989:9).

In my view natural landscape means the culturally classified but physically untransformed natural environment. It is an environment experienced by human beings. My use of the term "natural landscape" is in some respects similar to Orvar Löfgren's term "mindscape", and in some respects matches Agneta $\AA$ Akerlund's use of the term "physical environment". Akerlund presumes that Stone Age hunter-gatherers lived in a largely unaltered physical environment ( $\AA$ kerlund 1996:24).

The term cultural landscape will be used for an environment more or less transformed by human activities. The physical evidence of this transformation is the material culture aspect of the landscape. I agree with the above definition of fossil cultural landscape.

To sum up, in my opinion paleoenviron- ment excludes culturally interacting human beings. Studying the paleoenvironment implies the reconstruction of natural processes as we believe they actually were. Landscape includes interactive human beings capable of transforming the natural environment into a cultural landscape.

\section{NATURE-CULTURE \\ TRANSFORMATIONS}

In this section nature-culture relations will be commented on with special emphasis laid on understanding the transformation of nature to culture. The meaning of the concepts "nature" and "culture" is a cultural construction which can be understood within unique social processes (Hodder 1990). The terminology of landscapes, as stated above, implies human interaction, both mental and physical such. Human interaction in natural environments implies the transformation of nature into culture. Natural landscapes in this survey are defined as "cultural" in comparison with natural environments. Understanding how an environment is transformed into a landscape presupposes an understanding of the ideology of the studied society.

It is my intention to discuss natural landscape and cultural landscape as aspects of cultural transformation of the natural environment. Human interaction in a natural environment generates the transformation into a natural landscape. Human beings have a need to ideologically classify their surroundings in order to deal with them (Burström 1996:170). In this respect the transformation could be understood, for example, through the giving of names. Names are said to have crucial importance for the creation of landscapes. "Place names are of such vital significance because they act so as to transform the sheerly physical and geographical into something that is historically and socially experienced. The bestowing of names creates shared existential space out of a blank environment" (Basso 1984:27; Weiner 1991:32). In this case we are dealing with the mental landscape or "mindscape" (Löfgren 1989). The name-giving 
relates to conceptualisation of landscape through space and place. Without places there can be no spaces. Space provides a context for place and at the same time derives its meaning from place. Places are more than points and locations because they have distinctive values to persons (Tilley 1994:15). "In small-scale non-Western societies place, defined as a centre for action, intention, and meaningful concern, can be best considered in terms of locales and the wider context in which these locales occur - the cultural and natural landscape" (1994:18).

The "creation" of cultural landscapes relates to the actual transformation of the physical environment into material culture. This transformation also takes place within a specific ideological context related to a unique social process. In the early Mesolithic huntergatherer sense, this may be the working of raw materials into cultural items that is material culture. It may also be the clearing of trees and digging the postholes in preparation for a campsite. Some of these activities may leave evidence preserved over millennia and constituting a fossil cultural landscape (Welinder 1993:51).

\section{HUNTER-GATHERERS IN}

\section{THE MESOLITHIC}

In an article discussing Mesolithic research in Sweden 1986-1990, Kjel Knutsson makes a statement concerning research on the Mesolithic. In his view we should put less emphasis on descriptions of what we have found and concentrate more on the fundamentals of hunter-gatherers as humans (1995:7).

In the study of the colonisation of eastern middle Sweden we will put forward questions concerning the interpretation of the landscape of early Mesolithic hunter-gatherers. I believe in a restrained use of generalisations over hunter-gatherer's ideology and perception of environment. Generalisations of this kind have been criticised by cultural anthropologists during the last decade. These anthropologists argue for contextualism and a critical perspec- tive. Helena Knutsson (1995) refers to the criticism of generalisations, but she argues somewhat against it and points to the positive possibilities for archaeological analyses with regard to common characteristics of mobile hunter-gatherers (Knutsson 1995).

There is a considerable variation amongst hunter-gatherer societies with respect to mobility and storage. The difference concerns groups that are mobile and do not store food, and groups that are less mobile, store food and have a more specialised economy. This contrast also implies differences in ideology (Woodburn 1982). In connection with anthropological research in archaeology, the worldview of hunter-gatherers has, for example, been described as non-Western and pre-capitalistic (Tilley 1994:20). Mesolithic ideology has also been referred to as "primitive thinking", "wild thinking" or "prescientific thinking" (Welinder 1993:70).

With reference to the above-stated importance of name-giving, it seems reasonable that Mesolithic hunter-gatherers had names for landmarks in the natural landscape, for example ridges and rock outcrops (Tilley 1994:83). Following Tilley, it seems reasonable to take topographical features into consideration when studying the distribution of find-spots within a landscape of Mesolithic hunter-gatherers. This could be a method for making interpretations of the natural landscape. An interpretation of a Mesolithic huntergatherer landscape may imply a presumption of prescientific thinking. When it comes to classification of the surroundings a consciousness of totemistic classification is suggested prior to a Western-world classification.

In my view the way in which cultural anthropologists and archaeologists have generalised over totemistic relations between human beings and the natural environment that is transforming into a meaningful landscape, should be kept in mind when trying to interpret the way Mesolithic hunter-gatherers related to the natural environment. Here the word "related" has a double meaning associating to totemistic classification of social 
relations through ancestral relations as well as to classification of natural features in a mythological sphere.

Very briefly, a totemistic classification may mean giving individuals or groups of people names that are related features in the natural environment, for example topographical features or animal species (Lévi-Strauss 1972). The classification implies social structuring through a mythological sphere in which social relations and relations to natural features are the same, which puts this thinking out of Western-world logic (Tilley 1991). The totemistic way of perceiving the natural landscape gives a cultural meaning to the natural landscape, for example through the use of ancestral connections or kinship in name-giving and classification. A totemistic cosmology through mythology gives a certain meaning to natural features. One way of making interpretations of Mesolithic hunter-gatherer's natural landscapes is to consider totemistic ways of classification. In future studies natural features will be discussed not only for functional and economical reasons but also for ideological reasons.

\section{THE CULTURAL PRECONDITIONS FOR THE COLONISATION OF EASTERN MIDDLE SWEDEN}

Some crucial preconditions for the early Mesolithic occupation of eastern middle Sweden may be analysed in the light of the fact that the colonisers already carried cultural traditions concerning landscapes outside this area. One way of studying the origin of these groups is to analyse functional, ecological and ideological relations to the environment and make comparisons with groups in earlier populated regions. Another way is to study the material remains, for example flint and quartz debitage (Knutsson 1988:177). An analysis of foreign raw materials, local raw materials, and knapping techniques may result in interpretations concerning the origin of the human beings who left the debitage.
EASTERN MIDDLE SWEDEN:

A GLACIAL ENVIRONMENT TRANSFORMING INTO A CULTURAL LANDSCAPE

The Gladö investigations include archaeological investigations and paleoenvironmental studies carried out by quaternary geologists (Risberg 1996). This means studies and results generated by two different perspectives on the landscape formation and paleoenvironmental development, one archaeological and one quaternary geological. The investigations follow parallel, independent, research strategies but also aim at a co-operative research strategy. In presenting interpretations of the paleoenvironment/landscape, especially the natural aspects, this makes it possible to present either a common interdisciplinary interpretation or separate interpretations with reference to the different theoretical standpoints. In this respect the Glado investigations are part of a long tradition of interdisciplinary research in eastern middle Sweden (Åkerlund et. al. in press). The environment is more or less continuously transforming due to shore displacement, which has to be considered when analysing spatial patterns concerning prehistoric sites (Åkerlund 1996:136). The shore displacement phenomenon leaves us not only with a fossil cultural landscape but a fossil natural environment.

To quaternary geologists, the area has been of interest for investigations of the environmental development. The area was deglaciated c. $10.000{ }^{14} \mathrm{C}$ years BP(Brunnberg et. al. 1985). The environment has been in constant change due to shore displacement since the ice withdrew. The shore displacement in eastern middle Sweden has frequently been studied, especially through analyses of sedimentary basins on the Södertorn peninsula since the beginning of the 1970s (Risberg 1991).

There are several sedimentary basins with well-defined isolation thresholds at different altitudes. An important task has been to reconstruct the shore displacement sequence, in an attempt to understand regression stages, standstills and transgressions.

Within the Gladö investigations an inter- 
disciplinary research strategy makes it possible to interpret the paleoenvironmental and landscape formation from a quaternary geological as well as an archaeological perspective. Already in the phase of preliminary excavation, the area was surveyed for relevant sampling sites for stratigraphical analyses by Jan Risberg (1996). The survey aimed at sampling the entire area prior to any kind of disturbance of the sampling sites by the planned recycling plant. So far the geological research in the Gladö area has resulted in brief knowledge of sedimentary basins suitable for further analyses. Three of the sites have been discussed in a seminar paper that focuses on problems concerning shore displacement during the Yoldia and Ancylus stages of the Baltic Sea (Hedenström 1996).

The geologists are studying a paleoenvironment that, in archaeological respect, for the first time became a landscape of early Mesolithic hunter-gatherers. Paleogeographical maps based on stratigraphical results were made prior to the archaeological surveys of the area (Hammar in Åkerlund et. al. 1995) (fig. 2).

\section{THE HANVEDEN AREA}

Until 1991 no Mesolithic sites were known in the Hanveden area in central Södertörn. The initial discovery was made by a private researcher near a cottage named "Paradiset". At this place quartz debitage was found at altitudes c. 70 m.a.s.l. With the presumption that the site was shorebound this indicates a population present almost as soon as an archipelago was formed after the withdrawal of the ice sheet (cf. fig. 2).

Until 1991 the Eklundshov site partly excavated in 1986, was the earliest known

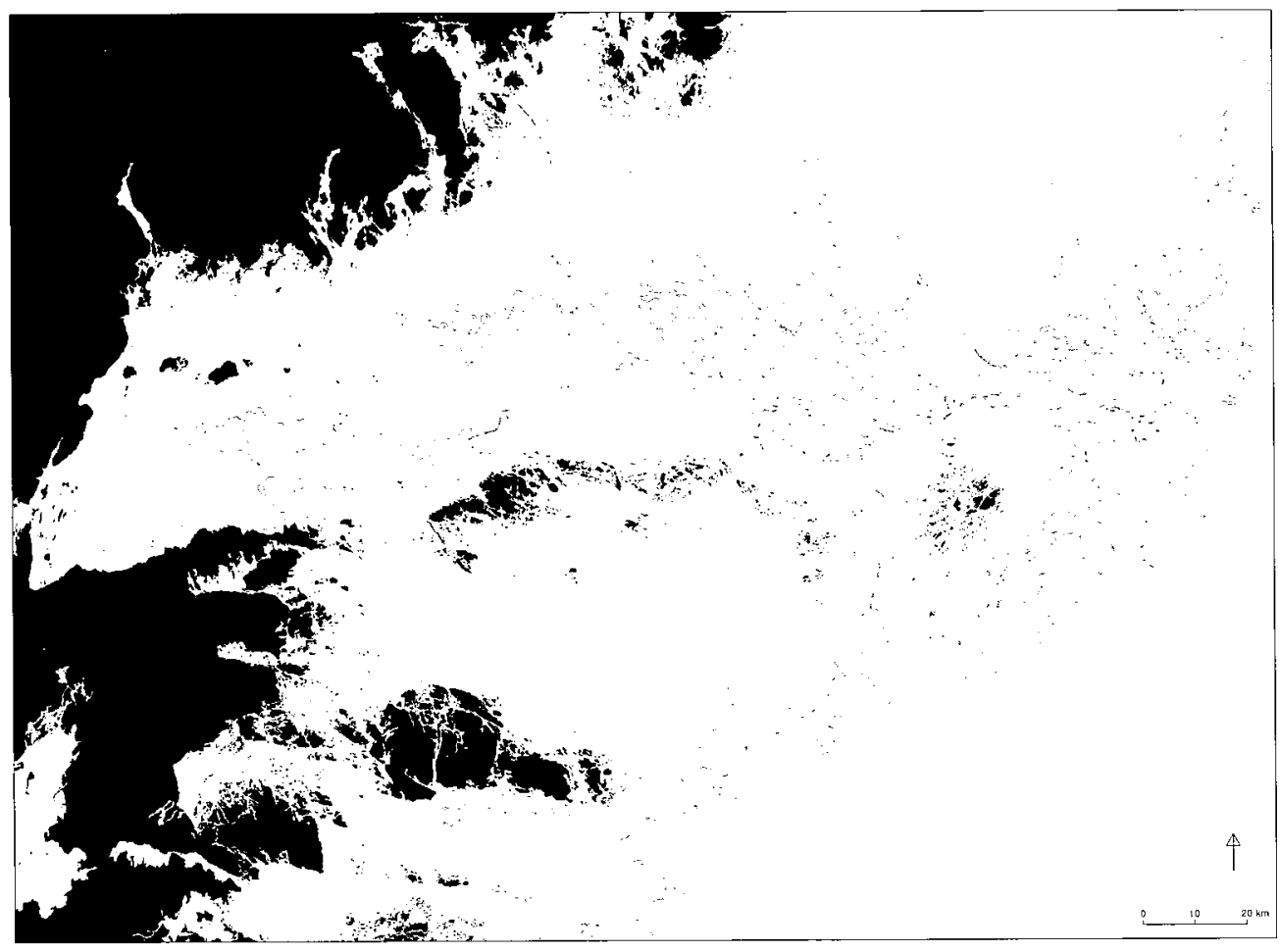

Fig. 2. Paleogeographical map of eastern middle Sweden, showing the shoreline at 75 m.a.s.l., based on the key map. According to the shore displacement model by Risberg et. al. (1991) it corresponds to dates of c. $9000{ }^{14} \mathrm{C} \mathrm{BP}$ at Södertörn. Note that the shorelines in the northern and southern parts are not synchronous. Drawing by R. Wikell and D. Hammar, UV. (After Åkerlund 1996, fig. 5:33a). 
Mesolithic site in the region with dates to 8200 ${ }^{14} \mathrm{C}$ years $\mathrm{BP}$ (Gustafsson \& Lindgren in press). The Eklundshov site was situated in the northwestern part of Södertörn at altitudes 61-58 m.a.s.1 (fig. 3). The site lies in the vicinity of a concentration of younger Mesolithic sites situated c.35-55 m.a.s.l. on the western half of the Södertörn peninsula.

A survey of Mesolithic sites in the central part of Södertörn, the Hanveden area, was initiated in 1991 (Hammar \& Wikell 1996). To give impetus to the survey, a preliminary hypothesis that the sites had been shorebound was accepted. Initially, special attention was paid to sandy slopes with southern exposure. In a later stage of the survey, presumed early Mesolithic shorelines were followed with an open mind to all kinds of localisations (Hammar \& Wikell 1994). Favourable localisation in relation to communication and the choice of natural resources was also considered when surveying the area (Hammar \& Wikell 1996). Sites on sheltered sandy slopes with a southern exposure occur, but this is only one type of location (fig. 4a-b). In the Södertörn district there are no base camps in the pioneer phase.
The survey so far has resulted in the discovery of more than 300 sites, half of which are situated over 60 m.a.s.l. (Åkerlund et. al. 1995:118).

One of the most astonishing results of the survey is the great number of new sites in an area that, prior to the work, was a blank space in terms of prehistoric remains. The achievements open up a new field of research on the Mesolithic in the area.

The distribution pattern of the sites was given an economical/functional interpretation. If we try to think of the results in terms of a fossil cultural landscape, the physical traces of human activities are evident. Hammar \& Wikell suggests a study of the relation between these traces and topographical features, especially features related to communication and subsistence strategies. The use of paleogeographical maps for the altitudes 80 and 70 m.a.s.l. is crucial to this study (cf. fig. 4 a-b). The authors suggest that the agglomeration of sites to specific parts of the landscape have functional explanations, for example, optimal communication or the possibility of a multiple choice economy.

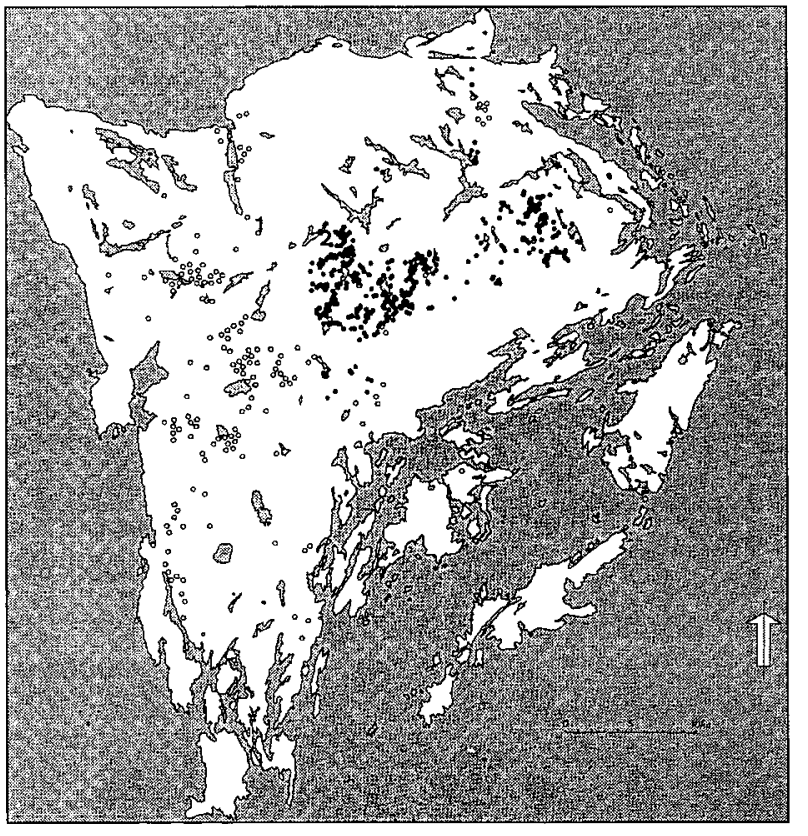

Fig. 3. Stone Age sites on Södertörn. o Stone Age sites known in 1990.

- Stone Age sites found in 1991-1994. 1 - Eklundshov.

$2-$ Gladö. (Modified from Hammar \& Wikell 1996, fig. 5). 


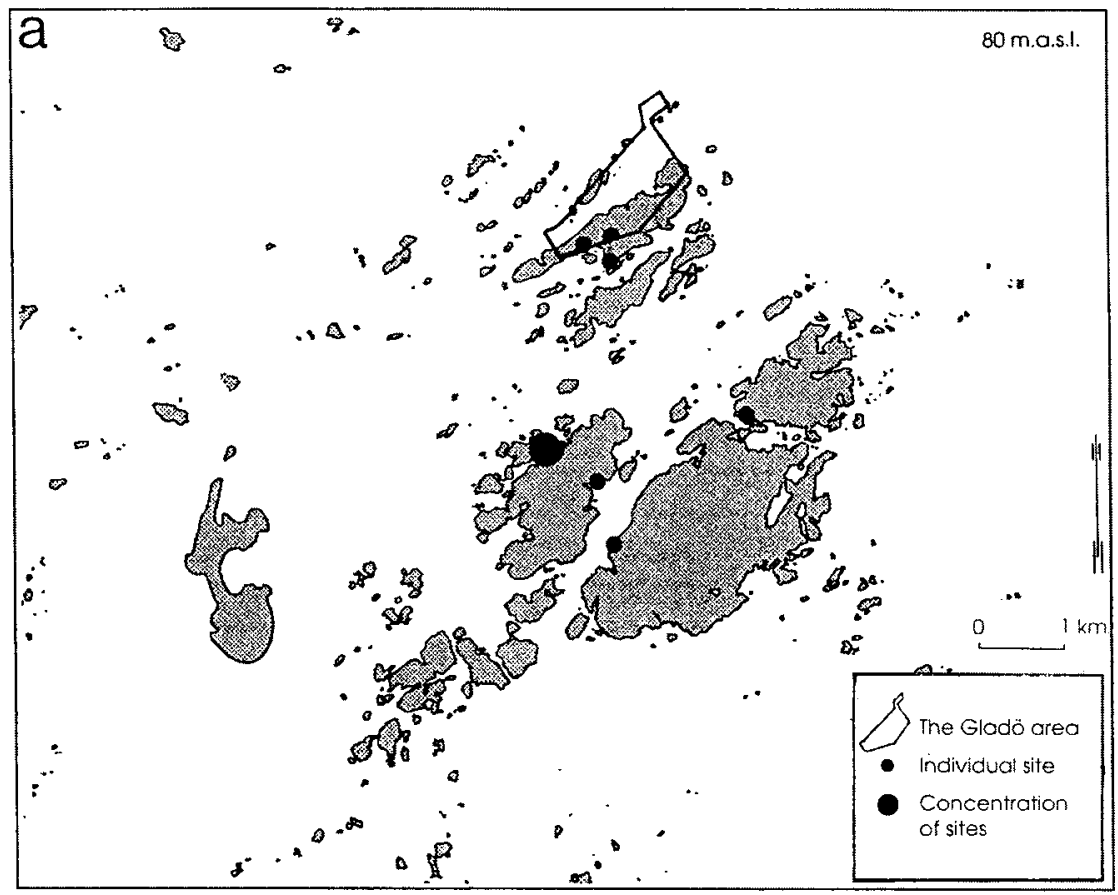

Fig. 4. Paleogeographical maps of Södertörn, with the shoreline at 80 m.a.s.l.(a), and 70 m.a.s.l. (b). Small dotsmark individual sites and big dots concentrations of sites. (Modified from Hammar \& Wikell 1996, fig. 4).

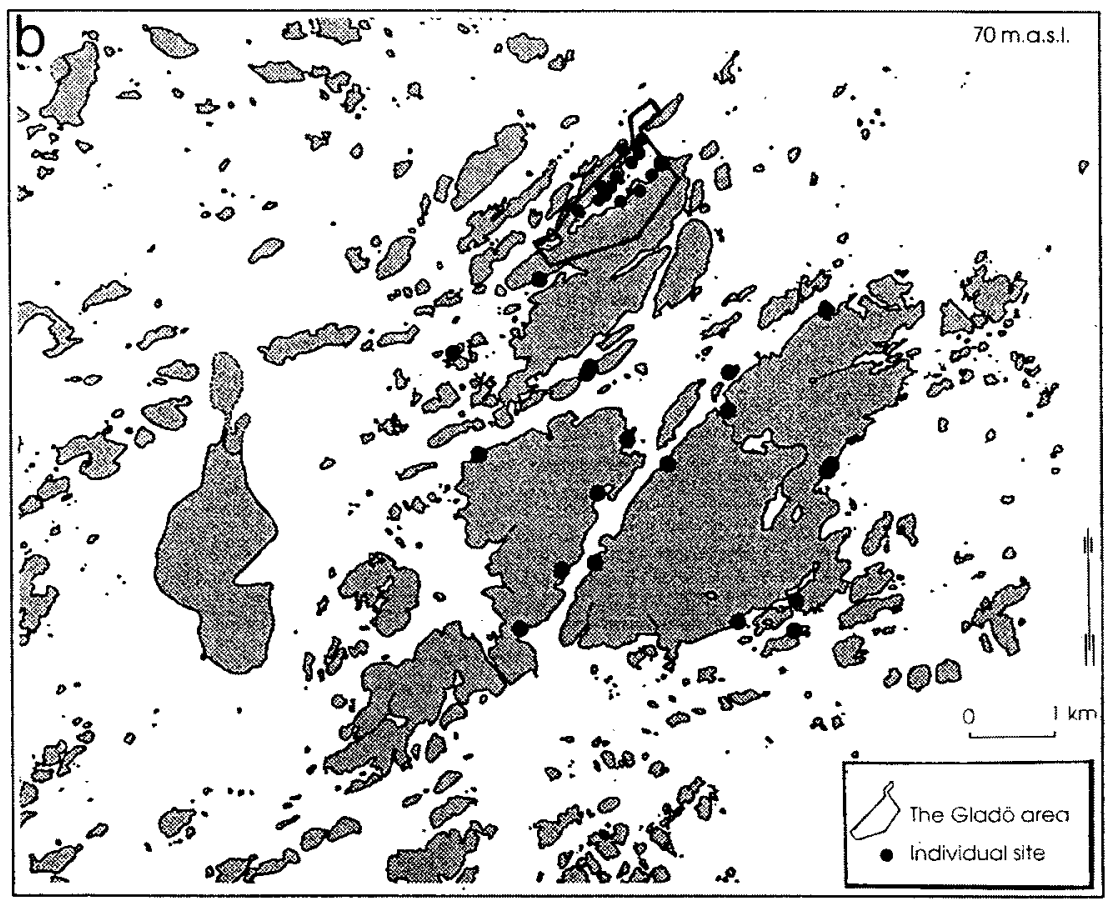


Sites at high altitudes have been found within two other parts of eastern middle Sweden, the Kolmården and Hälleforsnäs areas. However these areas have yet to be surveyed intensively with the aim of finding sites on high altitudes (Åkerlund et. al. 1995). The three areas of Kolmården, Hälleforsnäs and Södertörn are compared with respect to site size and the number of sites. There are differences among the districts concerning available resources and the distance to the mainland in the west. The authors discuss the reason for choosing a mobile life which did not seem necessary with respect to resource stability. The mobile life may have been preferred for social reasons ( $\AA$ kerlund et. al. 1995:118).

The sites in the Hanveden area are presumed to have been shorebound and there are certain factors supporting this presumption. There are concentrations of sites at certain altitudes, there are no sites above 82 m.a.s.l., and there are no sites bound to the shores of lakes or fenmargins of today. If the presumption that the sites were shorebound is right, sites at altitudes around 80 and 70 m.a.s.l. would be older than $9000{ }^{14} \mathrm{C}$ years BP. This indicates a phase of occupation when southern, western and north-western Scandinavia and also regions situated to the east of the Ancylus lake (now the Baltic Sea) were populated. There are still no clear indications of the origin of the "colonisers". The preliminary dates suggest that the sites in eastern middle Sweden are contemporaneous with the cultural spheres of Maglemose in southern Scandinavia (Larsson 1990), with Hensbacka and Fosna on the Swedish and the Norwegian west coast respectively (Kindgren 1996; Nygaard 1989), and with Askola and Suomusjärvi in Finland (Matiskainen 1996). Also contemporaneous with the Gladö sites are the earliest settlements of northern Sweden, which so far are known from sites in a zone in central Norrland and not on the coast (Forsberg 1996). In this early stage of research in eastern middle Sweden the artefact assemblages must be studied in order to make comparisons with the abovementioned cultural spheres. It seems reasona- ble to look for artefact types or manufacturing techniques that are specific for each of these regions, leading us to an interpretation of which tradition our assemblages relate to. The possibilities of comparing environmental features of the coastal settlements will be somewhat limited when it comes to the southern parts of Scandinavia. Here the early Mesolithic shorebound areas have subsided due to sealevel changes and are now submerged. There are only inland bog sites dated to these periods (Larsson 1990:263).

The early Mesolithic artefact assemblages of eastern middle Sweden so far do not give grounds for an interpretation of which cultural traditions outside the area they are related to. Sites at altitudes over 80 m.a.s.l. lack foreign raw materials, and the assemblages are dominated by quartz knapped with the platform method. Sites at levels under 80 m.a.s.l. are mixed with respect to the platform and bipolar methods. From 70 m.a.s.l. and lower there are occasional finds of flint artefacts and artefacts of local raw materials like dolerite (Åkerlund et. al. 1995). Detailed records of the artefacts found during the surveys have not yet been published.

\section{THE GLADÖ SITES}

The Gladö area is situated immediately to the north-west of the surveyed part of Hanveden on the Södertörn peninsula south of Stockholm (cf. fig. 4a-b ). As mentioned, the archaeological investigations were carried out prior to planned exploitation of the area. Following national legislation, the area was surveyed for ancient remains in 1993 prior to the exploitation. The survey included the digging of test pits (Kihlstedt 1993). There were expectations of finding Mesolithic sites since the area was situated close to the previously surveyed part of Hanveden.

When surveying this area attention was paid to various topographical localities. Some of the larger areas with favourable topographical conditions like gentle sandy slopes were more intensively tested by a machine. Within the Gladö area 23 sites were found, 16 of 
which were classified as ancient sites with reference to national legislation. Two of the sites which are situated in the south-eastern periphery of the Gladö area were found already in the Hanveden survey.

The results from the first survey in Gladö have been discussed with reference to variation in the size of the sites in the area. Mikael Jakobsson and Britta Kihlstedt discussed the definition of the concept ancient monuments and the national legislation for protection of the cultural heritage (Jakobsson \& Kihlstedt 1995). The authors point out the importance of taking all remains of human activities into consideration when studying the formation of a Mesolithic cultural landscape. This implies sites that include concentrations of quartz debitage as well as sites with single artefacts. A related viewpoint is argued for by Agneta Åkerlund, who suggests a change in the use of the concept site to understand the land use of hunter-gatherers ( $\AA$ kerlund 1996).

The mining activities started in the southwest and will move to the north-east in an area measuring a total of $1.2 \mathrm{~km}^{2}$. The exploitation will take 30 to 40 years before it is completed. Only a few of the 16 sites will be excluded from excavation. In this opening stage investigations of the southern and central parts of the area will be carried out. From the survey and preliminary test pits we know that the sites are characterised by the appearance of quartz debitage. There are occasional finds of flint, and no indications of features like fireplaces, pits or postholes, or heaps of fire-cracked stones.

If the sites were shorebound, which we assume, the altitude $70 \mathrm{~m}$.a.s.l. seems to be relevant for more than half of the sites in the area. There are two sites situated around the 80 m.a.s.l. Site topography is variable, some sites are surrounded by outcrops of bedrock and other sites are situated in a more open location.

In 1995 the first preliminary excavation was carried out. The excavation concerned a site situated in the southern part of the exploitation area, site number 305 in the Register of Ancient Monuments (RAM). The preliminary excavation aimed at detecting horizontal and vertical spatial distributions of materialculture remains and determining how natural processes influenced in site formation. Attention was paid to preservation conditions for layers, features, bones, archaeobotanical material, density of artefact layers, and possibilities for geostratigraphical analyses on the site and in wetlands in the surrounding area. Additionally the intention was to interpret the horizontal distribution pattern of quartz debitage, to understand what kinds of activities took place on the site and what possibilities the source material had for analysing these activities. The preliminary excavation aimed at making an interpretative classification on a functional basis (Gustafsson 1996).

Trying to reconstruct functional aspects of the site was one aim that guided the choice of methods prior to the final excavation. The preliminary excavation resulted in a spatial distribution consisting of two concentrations of quartz debitage, all in all c. 120 fragments situated at 70-73 m.a.s.l. Within one of the concentrations was found one core, flakes, fragments of flakes and splinters. No tool types that match the typology of the period were found. The preliminary interpretation of the site was directed to functional aspects. One of the concentrations was interpreted as a knapping floor. The site seemed to have been visited on one or a few occasions to work quartz. Both the bipolar and the platform methods were detected from the quartz debitage found on the presumed knapping floor. None of the concentrations of quartz was completely excavated, and thus classification of flake fragments in order to analyse quartz fracture patterns within the framework of results from experimental series may be carried out after the complete excavation (Knutsson \& Lindgren in press; Callahan et. al. 1992).

The absence of organic material for ${ }^{14} \mathrm{C}$ dating is a problem which was not solved during the first preliminary excavation. The preliminary excavation of the RAM 305 site was followed by a complete excavation in the summer of 1996, the results of which are yet to 
be further analysed. Within the 1996 field season two more sites and an area with quartz veins in exposed outcrops of bedrock were preliminarily excavated.

The stone debitage found during the complete as well as the preliminary excavations has so far not given any clear indication of the origin of the population. The colonisation is presumed to have followed a distribution directed from the mainland in the west over the chain of islands in the east. This seems the most plausible interpretation with respect to travelling distances over open water ( $\mathrm{ker}$ lund et. al. 1995:118). The closest parallels with regard to stone technology are, however, found in present-day Finland, but this has to be studied more closely (ibid.).

\section{LANDSCAPE TERMINOLOGY APPLIED} TO THE GLADÖ INVESTIGATIONS

Preconditions in Gladö and Hanveden are favourable for the application of landscape terminology. The physical environment is well preserved, and there are hundreds of sites containing traces of human activities. This is a good basis for studying the paleoenvironment, natural landscape and cultural landscape. It seems reasonable that Mesolithic ideas concerning naturally shaped and culturally shaped phenomena were not kept apart. In studying the first occupation of this area, there appears to be an opposition between the uninhabited paleoenvironment on the one hand and the natural and cultural landscape on the other. Up to now the investigations in the Gladö area have put emphasis on analysing the cultural landscape through the physical evidence of human activities. The next steps in the analyses of these concepts will include an interpretation of the Mesolithic natural landscape as a phenomenon linked to the ideology of huntergatherers.

Concentrations of quartz debitage, findspots or quarries are examples of features in the early Mesolithic cultural landscape. These features may be classified as remains of human transformation of natural phenomena into material culture and, to us, items of the fossil cultural landscape, but as stated above analysing this transformation may not be the key to understanding the early Mesolithic occupation of the area. More likely the natural landscape, that is the results of classification by Mesolithic hunter-gatherers, has to be interpreted from the appearance of the fossil cultural landscape and the paleoenvironment.

Prior to the preliminary excavations site location was discussed in terms of economy and communication including human beings in an economic perspective (Gustafsson 1996). In studying paleoenvironments that are transformed into natural landscapes, interpretations of ideological aspects of Mesolithic hunter-gatherers will be introduced.

Site location with respect to landmarks, such as features in the natural topography, has yet only been considered to a limited extent. So far topographical features have been considered for functional interpretations such as a ridge giving wind shelter or a quartz vein giving raw material for tool making. Natural landscape in the minds of Mesolithic huntergatherers has been placed beyond the reach of interpretation. The environmental and cultural preconditions present in the Gladö area inspire and support the development of a new perspective. The topography of this environment is dramatic (fig. 5). It contains narrow fissure valleys flanked by ridges, outcrops of bedrock fossil islands, steep and gentle slopes, characteristic shapes and broad quartz veins. These are some of the characteristics of the fossil environment. Due to land upheaval, these features are preserved at high altitudes and have not been disturbed by exploitation since the early Mesolithic occupation.

THEUNDERSTANDINGOF LANDSCAPE IN THE GLADÖ AREA, AN EXAMPLE It is assumed that natural features of Mesolithic hunter-gatherers were classified through mythical cosmologies and given a symbolic meaning. In archaeological analyses the fossil cultural landscape and the paleoenvironment will be the media through which interpretations concerning the natural landscape will be 


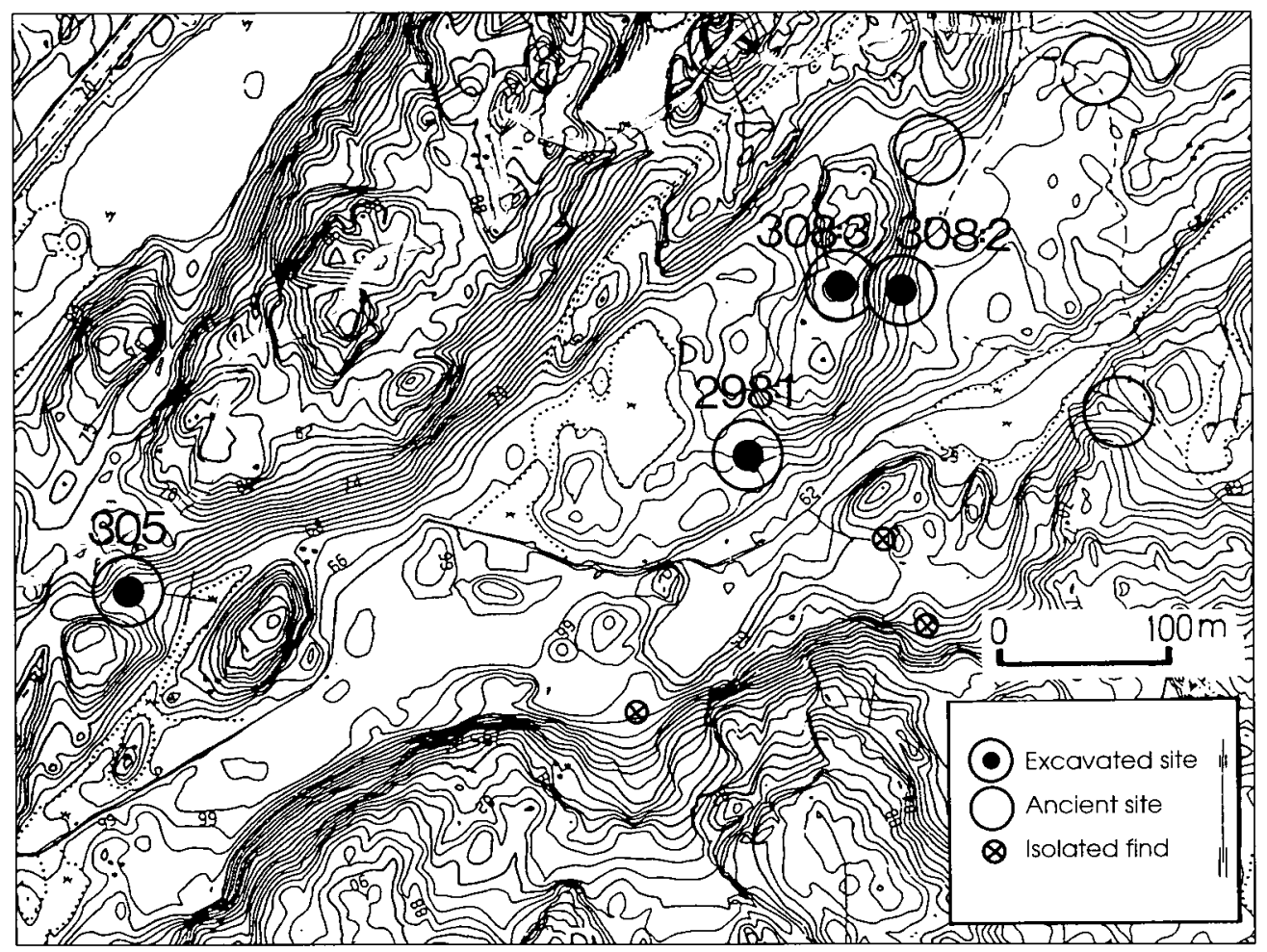

Fig. 5. Topography in the central part of the Gladö area. (Contours in 1 m intervals.)

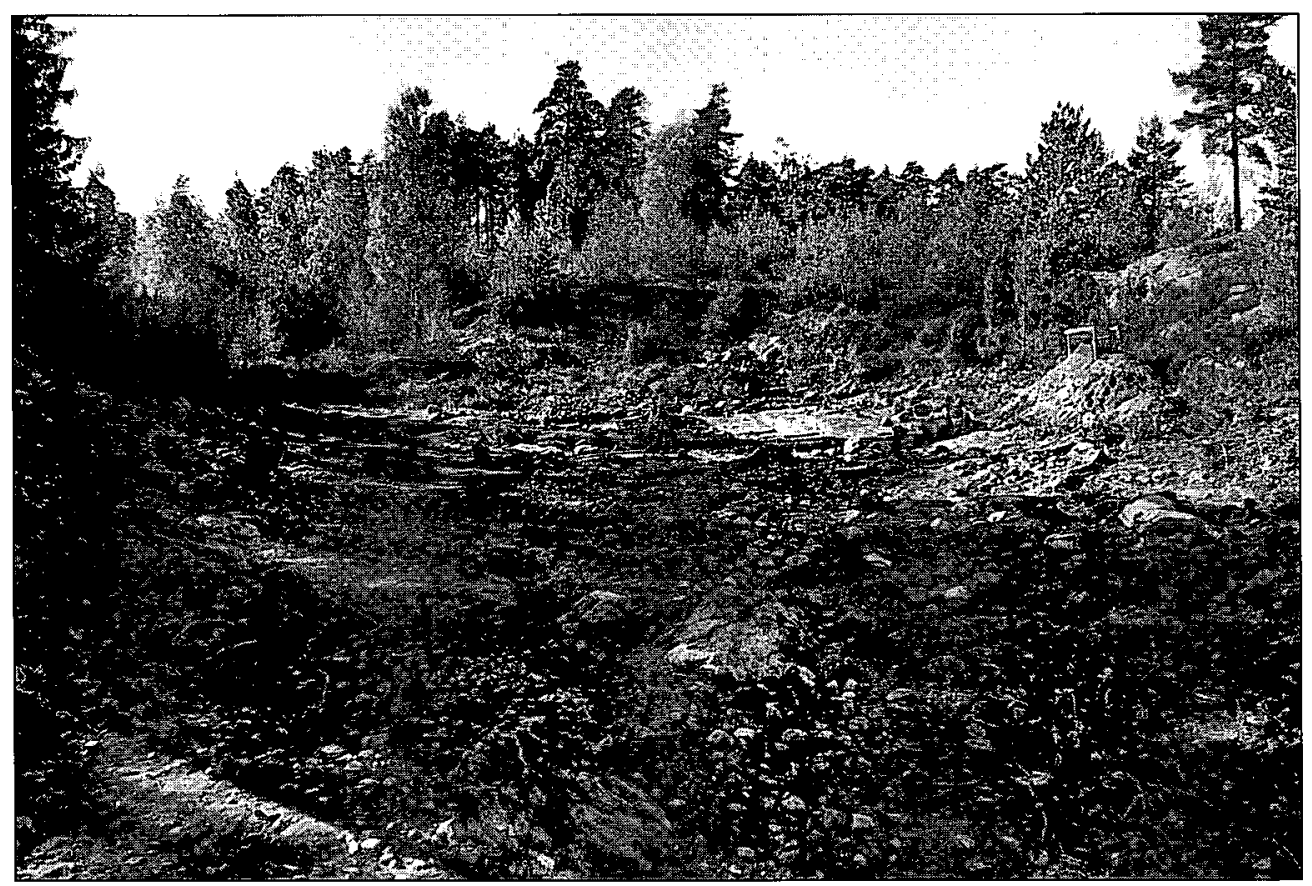

Fig. 6. The site RAM 305 during excavation. Photo P. Gustafsson. 
formulated. In the coming stage of investigation, studies of the spatial distribution of ancient sites in the context of topographical landmarks will be carried out. The following example illustrates the relation between the natural and the cultural landscape terminology.

In the example, results from the excavations in the Gladö area such as site distribution patterns and intrasite structures are discussed in relation to structures in the natural surroundings. Variations concerning boundaries, inside/ outside relations, and open/closed structures are considered. In the first excavated site the distribution of quartz was characterised by limited concentrations. The plateau was surrounded by outcrops of bedrock (fig. 6). The quartz debitage was situated in limited concentrations within the site. The site was open to a narrow strait and at the opposite side of the strait a small island was situated. From this site the larger part of the bay was not visible. During the preliminary excavation of new sites in 1996, other types of locations and different distribution patterns were observed.

The site RAM 308:2 had an unbounded character. There were slight variations in the topography, but the spatial distribution of quartz did not coincide with the best topographical localities. Quartz debitage was spread along the Mesolithic shore without being concentrated and without limitations, in contrast to the situation on the first excavated site. This preliminary comparison reveals a difference between the site with boundaries and the open site, which may serve as a point of departure for interpretations of the Mesolithic hunter-gatherer's landscape.

A site like the first excavated RAM 305 has a spatial restriction; it is a location, either a temporary camp or a site to work quartz (Tilley 1994). This site has an inside and an outside. The limitations of the inside are marked by cultural items and topographical features against the outside. In terms of identification the topographical boundaries may play an active role in relation to the inside camp, and the inside could be termed cultural in opposition to the natural outside. The unlimited site has no inside/outside relations of the same kind, and there are no means for interpretation of nature-culture contradictions. Material culture seems to "flow" without boundaries. A study of the site distribution pattern within the Gladö area reveals that the bounded sites are separated from the open sites, while the open sites lie in a concentration. In interpreting how hunter-gatherers create cultural identity, more attention should be paid to the natural environment instead of focusing on specific campsites as the most important key to understanding the creation of cultural identity (Engelstad 1990; Åkerlund 1996). It seems important to discuss insideoutside relations in the landscape regarding several spatial levels such as site, shore, bay, island, and district, when attempting to interpret this environment as an Early Mesolithic natural and cultural landscape.

The open site example also illustrates one major problem of rescue excavations in this area. Only some of the quartz finds can be put into a specific topographical context, a specific site or locale. A considerable part of the quartz debitage was found in places along the presumed Mesolithic shore outside of ancient sites in the legal respect. This means that, even without the discussion of the importance of topographical landmarks in this environment, entire sections of the paleoenvironment could be interpreted as fossil cultural landscapes with respect to the spatial distribution of quartz debitage.

\section{CONCLUSION}

More emphasis will be put on site topography and topographical features like natural landmarks in future investigations in the area (fig. 7). So far material-culture remains, that is quartz debitage, dominate the Early Mesolithic material. The analyses of quartz debitage, knapping techniques and quartz quarries have dominated our research. In an interpretation of the hunter-gatherers' landscape, quartz must be taken into consideration for possible symbolic qualities. Quartz debitage is the most evident component of the fossil cultural 


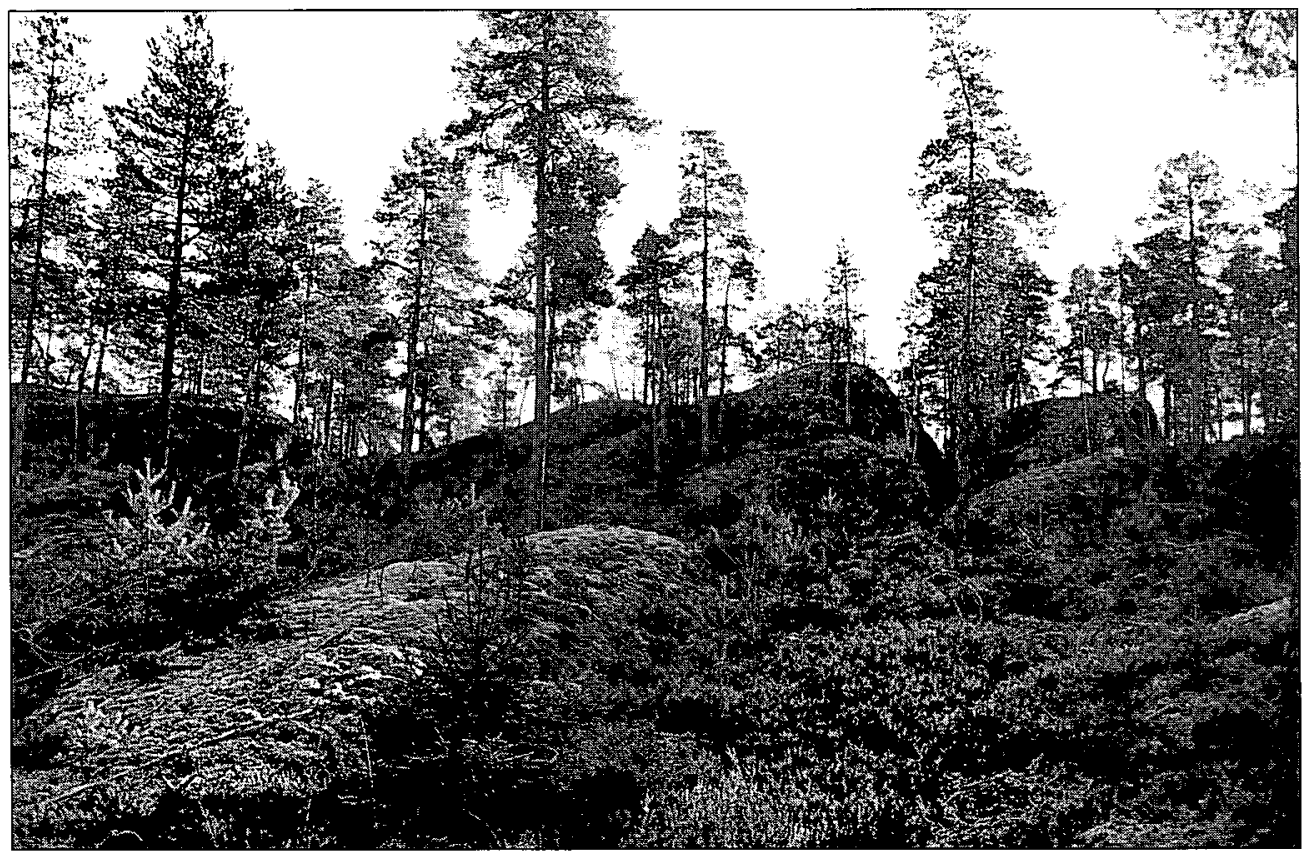

Fig. 7. View of topography in the Gladö area. Photo P. Gustafsson.

landscape and the most evident example of nature-culture transformation. The quarrying, knapping and the making of tools could be associated with social categorisations and could, for example, be genus related.

To support this theoretical perspective in Mesolithic research, some methodological improvements are suggested. Using Geographical Information Systems (GIS), would, I believe create a wider range of possibilities for taking features of the natural environment into consideration in interpretations of the landscape of Mesolithic hunter-gatherers. GIS permits the linking of various kinds of data to specific locations in a landscape. It combines digitised maps with databases in a way which allows for both spatial and semantic contents of a map ( $\AA$ kerlund 1996:114).

\section{A FINAL COMMENT CONCERNING THE PRESENT EXCAVATIONS}

Through the archaeological experience of Mesolithic man in a reconstructed paleoenvironment, the Gladö area is transforming into a meaningful contemporary landscape. As archaeologists, we are creating a landscape meaningful to us. We are recreating a landscape which has been created at least once before. The public interest in the excavations has increased. The Gladö area has transformed into a prehistoric landscape in the minds of people of today in step with the acceptance of the archaeological results.

\section{English revised by Laura Wrang.}

\section{ACKNOWLEDGEMENTS}

The author wishes to thank Agneta Akerlund (RAÄ) for critically reading the manuscript and Dag Hammar (RÄ̈) for giving valuable comments on the presentation of the results of the Hanveden survey. 


\section{REFERENCES}

Basso, K. 1984. Stalking with stories: Names, places and narratives among the western Apaché. In: Bruner, E.M. (Ed). Text, Play and Story. Prospect Heights. Waveland press, Illinois.

Bloch, M. \& Parry, J. (Eds). 1982. Death and the Regeneration of Life. Cambridge.

Brunnberg, L., Miller, U. \& Risberg, J. 1985. Project Eastern Svealand: Development of the Holocene Landscape. Third Nordic Conference on the Application of Scientific Methods in Archaeology. ISKOS 5. Pp. 85-91. Helsinki.

Burström, M. 1996. Gărdstankar. Kognitiva och sociala perspektiv på forntidens gårdar. In: Kyhlberg, O. (Ed). Hus \& Gärd i det förurbana samhället. Rapport frain ett sektorforskningsprojekt vid Riksantikvarieämbetet. Artikeldel. Stockholm.

Callahan, E. et. al. 1992. Frakturbilder. Kulturhistoriska kommentarer till det säregna sönderfallet vid bearbetning av kvarts. TOR 24. Pp. 27-63. Uppsala.

Engelstad, E. 1990. The meaning of sedentism and mobility in an archaeological and historic context. Acta Borealia 7/2. Pp. 21-35.

Forsberg, L. 1996. The Earliest Settlement of Northern Sweden - Problems and Perspectives. In: Larsson, L. (Ed). The Earliest Settlement of Scandinavia and Its Relationship with Neighbouring Areas. Acta Archaeologica Lundensia. Series in $8^{\circ}$, No 24.

Gustafsson, P. 1996. Arkeologisk Förundersökning. Gladö bergtäkt RA $\ddot{A} 305$. Riksantikvarieämbetet UV Stockholm Rapport 1996:3.

Gustafsson, P. \& Lindgren, C. in press. The Eklundshov site. In: Akerlund, A. et. al. (Eds). in press. Södertörn.

Hackens, T. et. al. (Eds). 1995. ${ }^{14} \mathrm{C}$ Methods and Applications. A Symposium Dedicated to Ingrid Olsson on the Occasion of a Birthday. PACT 49.

Hammar, D. \& Wikell, R. 1994. Nyupptäckta stenălderboplatser på Södertörn. Arkeologi $i$ Sverige. Ny följd 3. Riksantikvarieämbetet. Pp. 217-223. Stockholm.

- 1996. 250 nyupptäckta stenålderslokaler på Södertörn. In: Bratt, P. (Ed). Stenålder i Stockholms län. Pp. 15-21.

Hedenström, A. 1996. Preboreal shore displacement on central Södertörn peninsula eastern middle Sweden. Quaternaria. Ser.B: Rapporter och meddelanden $N r$. 7. Stockholm.

Hodder, I. 1990. The Domestication of Europe. Structure and Contingency in Neolithic societies. Blackwell Publishers. Oxford.
Jakobsson, M. \& Kihlstedt, B. 1995. Boplats eller fyndplats - om fornlämningsbegreppets tilllämpning. Kulturmiljövård 3//995. Riksantikvarieämbetet. Stockholm.

Kihlstedt, B. 1992. Arkeologisk utredning Etapp 1. Gladö industriområde. Björksättra 1:4, Huddinge sn, Södermanland. Riksantikvarieämbetet, UV Stockholm Rapport 1992:45.

- 1993. Arkeologisk utredning. Gladö industriområde. Björksättra 1:3, Huddinge sn, Södermanland. Riksantikvarieämbetet, UV Stockholm Rapport 1993:62.

Kindgren, H. 1996. Reindeer or seals? Some Late Paleolithic Sites in Middle Bohuslän. In: Larsson, L. (Ed). The Earliest Settlement of Scandinavia and Its Relationship with Neighbouring areas. Acta Archaeologica Lundensia. Series in $8^{\circ}$, No 24.

Knutsson, H. 1995. Slutvandrat? Aspekter påövergången från rörlig till bofast tillvaro. AUN 20. Uppsala. Diss.

Knutsson, K. 1988. Making and using stone tools. The analysis of the lithic assemblages from Middle Neolithic sites with flint in Västerbotten. Aun 11. Uppsala. Diss.

- 1995. Mesolithic research in Sweden 1986-1990. Current Swedish Archaeology, Vol. 3. Stockholm.

Knutsson, K. \& Lindgren, C. in press. Making sense of quartz. Presentation and results of an experimental analysis applied to quartz from a number of sites in Södertörn. In: Àkerlund, A. et. al. (Eds). in press. Södertörn.

Kyhlberg, O. (Ed). 1996. Hus \& Gärd i det förurbana samhället. Rapport från ett sektorforskningsprojekt vid Riksantikvarieämbetet. Artikeldel. Riksantikvarieämbetet. Arkeologiska undersökningar. Skrifter nr 14.

Larsson, L. 1990. The Mesolithic of Southern Scandinavia. Joumal of World Prehistory 4/3. Pp. 257-309.

- (Ed). 1996. The Earliest Settlement of Scandinavia and Its Relationship with Neighbouring Areas. Acta Archaeologica Lundensia. Series in $8^{\circ}$, No 24.

Lévi-Strauss, C. 1972. The Savage Mind. The Nature of Human Society. Weidenfeld and Nicolson.

Löfgren, O. 1989. Landscapes and mindscapes. FOLK 31.

Matiskainen, H. 1996. Discrepances in Deglaciation Chronology and the Appearance of Man in Finland. In: Larsson, L. (Ed). The Earliest Settlement of Scandinavia and Its Relationship with Neighbouring Areas. Acta Archaeologica Lundensia. Series in $8^{11}$, No 24. 
Nygaard, S. E. 1989. The Stone Age of Northern Scandinavia - a review. Journal of World Prehistory 3. Pp 71-116.

Risberg, J. 1991. Paleoenvironment and sea level changes during the early Holocene on Södertörn peninsula, Södermanland, eastern Sweden. Stockholm University, Department of Quaternary research. Report 20. Stockholm. Diss.

- 1996. Arkeologisk Förundersökning. Gladö bergtäkt - stratigrafiska undersökningar. Riksantikvarieämbetet UV Stockholm Rapport 1996:78

Risberg, J. et. al. 1991. Deglaciation, Holocene shore displacement and coastal dwelling in eastern Svealand, Sweden. Quaternary International 9. $\mathrm{Pp}$ 33-37.

Robertsson, A.-M. et. al. (Eds). Landscapes and life. Studies in honour of Urve Miller. PACT 50.

Sporrong, U. 1989. Från objekt till miljö. Kulturmiljövård, I/89. Riksantikvarieämbetet. Stockholm. Pp 9-14.

Tilley, C. 1991. Material Culture and Text. The art of ambiguity. London.

- 1994. A Phenomenology of Landscape. Bergh publishers. Oxford.

Weiner, J. 1991. The Empty Place. Indiana University Press. Bloomington.

Welinder, S. 1992. Människor och landskap. Aun 15. Uppsala.
- 1993. Miljö, kultur och kulturmiljö. Almqvist \& Wiksell. Stockholm.

Woodburn, J. 1982. Social dimensions or death in four African hunting and gathering societies. In: Bloch, M. \& Parry, J. (Eds). Death and the Regeneration of Life. Cambridge.

Åkerlund, A. 1996. Human Responces to Shore Displacement. Living by the Sea in Eastern Middle Sweden during the Stone Age. Riksantikvarieämbetet. Arkeologiska undersökningar, Skrifter nr 16. Stockholm. Diss.

Åkerlund, A., Hammar, D. \& Wikell, R. 1995. Pioneers in the archipelago of Eastern Middle Sweden 9000 BP. In: Robertsson, A.-M. et. al. (Eds). Landscapes and life. Studies in honour of Urve Miller. PACT 50. Pp. 109-120.

Åkerlund, A., Olsson, E., Gustafsson, P, \& Miller, U. (Eds). in press. Södertörn. Interdiciplinary investigations of Stone Age sites in Eastern Middle Sweden. Riksantikvarieämbetet. Stockholm.

Åkerlund, A., Risberg, J., Miller, U. \& Gustafsson, P. 1995. On the applicability of the ${ }^{14} \mathrm{C}$-method to interdisciplinary studies on shore displacement and settlement location. In: Hackens, T. et. al. (Eds). ${ }^{14} \mathrm{C}$ Methods and Applications. PACT 49. Pp. 53-84. 